\title{
Phosphorus supplementation to natural pasture grazing for beef cows in the Western Highveld region of South Africa
}

\author{
C.H.M. de Brouwer ${ }^{1 *}$, J.W. Cilliers ${ }^{1}$, L.M. Vermaak $^{1 \#}$, H.J. van der Merwe ${ }^{2}$ and P.C.N. \\ Groenewald $^{3}$ \\ ${ }^{1}$ Department of Agriculture, North West Province, Directorate of Technical Support Services, Private Bag X804, Potchefstroom, \\ 2520, South Africa. Departments of Animal Science ${ }^{2}$ and Mathematical Statistics ${ }^{3}$, University of the Orange Free State, \\ Bloemfontein, 9300, South Africa
}

\begin{abstract}
Simmentaler cows grazing Cymbopogon-Themeda veld in the western Highveld region of South Africa (1985/861989/90) received three levels of phosphorus (P) supplementation. Dicalcium phosphate content of the supplement was manipulated to give intakes of 8 (CS), 4 (HS) or 0 (ZS) g P/cow/day during summer. All cows received supplemental P (10 g/cow/day) during winter (1986-1989). In 1990, supplemental P (10 (CW), 5 (HW) or 0 (ZW) g P/cow/day) was given in a winter maintenance supplement (protein, energy and minerals). Rainfall was above average during the trial period. Reproductive performance was not influenced by P supplementation. Mean livemass of the CS group was greatest $(p<$ $0.01)$, and that of HS was greater $(p<0.01)$ than ZS at the end of summer. Both CS and HS had better $(p<0.01)$ condition scores than ZS. Bone P content was lowest and indicative of deficiency $(p<0.01)$ in ZS cows (112.6 vs 141.9 and 130.8 $\mathrm{mg} \mathrm{P} / \mathrm{cm}^{3}$ bone for CS and HS respectively). Calf performance was not affected $(p>0.05)$ by P supplementation. Cow mass was affected by winter P supplementation $(p<0.05)$. Both CW and HW displayed improved $(p<0.01)$ condition scores and higher $(p<0.01)$ bone P content than ZW. Fatalities (4) occurred in ZW due to P deficiency $\left(74.5 \mathrm{mg} \mathrm{P} / \mathrm{cm}^{3}\right.$ bone), and deficiency symptoms were manifested in the entire group. Both summer and winter veld is deficient in $\mathrm{P}$, which makes continuous supplementation a recommended practice in this area.
\end{abstract}

Keywords: Phosphorus, supplementation, beef cattle, veld.

* Author to whom correspondence should be addressed. Email: vkcdb@potch1.agric.za ${ }^{\#}$ Current address: ARC Animal Improvement Institute, Private Bag X2, Irene, 0062, South Africa.

\section{Introduction}

According to NRC (1984) recommendations, a $550 \mathrm{~kg}$ lactating cow requires $30 \mathrm{~g} \mathrm{P} /$ day $(0.27 \%$ of diet dry matter (DM)), and a dry, pregnant cow requires $19.5 \mathrm{~g}$ P/day (0.2\% of diet DM). P requirements also increase as level of production increases. In an extensive study of the mineral content of natural pasture (veld), Du Toit et al. (1940) found that the $\mathrm{P}$ content of grazing in many areas of South Africa is insufficient to support productive cattle. As a result of this, $\mathrm{P}$ supplementation became a general practice and had a marked effect on the reproduction and growth of cattle in some areas. These effects were, however, not evident in all regions and this, in turn, prompted further studies. Many reports have been published on P supplementation (Theiler et al., 1927; Theiler \& Green, 1932; Hemingway, 1967; Little, 1970; Ferreira, 1976; Read, 1984; Van Niekerk \& Jacobs, 1985; Groenewald, 1986; Jacobs, 1991; De Waal \& Koekemoer, 1993; De Waal et al., 1993; De Waal et al., 1996; De Waal \& Koekemoer, 1997; Spangenberg et al., 1993; Spangenberg, 1997). Heard (1971) stated that sub-clinical P deficiencies are more important than acute deficiencies, as the former results in loss of income and is difficult to quantify. Groenewald (1986) found that cows that did not receive P supplementation tended to calve only once every two years.

P supplementation increases weight loss when cattle are fed at levels below maintenance (Ferreira, 1976; Louw, 1979; Van Niekerk \& Jacobs, 1985). This appears to occur in cases where protein and energy requirements are not balanced by the supplement. It is important to note that responses to P supplementation vary substantially from one area to the next. Supplementation can be essential in one area and unnecessary in another area within the same region (Engels, 1981; Read, 1984; De Waal \& Koekemoer, 1993; De Waal et al., 1993; De Waal et al., 1993; De Waal et al., 1996; De Waal \& Koekemoer, 1997; Spangenberg, 1997). Extrapolation of results from one area to the next is therefore not recommended. Supplemental P is essential in the region to the west of the experimental site (Armoedsvlakte), but unnecessary in the region to the east (Glen; Read, 1984). This trial was done to determine whether beef cows in the Western Highveld region of the Republic of South Africa require supplemental P. 


\section{Material and methods}

The trial was conducted near Potchefstroom on the northern variation of Cymbopogon-Themeda veld (Acocks, 1988). The terrain is made up of undulating plains between andesite, diabase and quartsite ridges, and altitude varies from $1345-1420 \mathrm{~m}$. The average annual rainfall is $620 \mathrm{~mm}$. The nutritive value of grazing found on the plains, andesite and diabase ridges differs from that on the quartsite ridges and outcrops, which corresponds to the western variation of the Bankenveld (Acocks, 1988). This was taken into consideration during the allocation of camps to the different treatments. A summer stocking rate of 0.53 large stock units/ha (Drewes, 1991) was maintained.

Simmentaler cows were initially allocated at random to one of three levels of summer P supplementation (24 cows/treatment) within mass, age, calf-performance and constitution categories. However, as animals were replaced at a rate of $20 \%$ per year, this grouping was not taken into account in the statistical analysis. For the winter phase (1990), cows were randomly allocated to one of three levels of $\mathrm{P}$ supplementation within previous summer treatment ( 8 from each summer treatment). The winter treatment was done according to the multiple assignment tester technique, as described by Matches et al. (1974). Cows were mated during summer (mid-December to mid-February) and calved during spring (September to November). Calves were weaned during May, at which time cows were culled at a rate of $20 \%$ per annum and replaced with pregnant heifers. Single-bull mating was applied, and bulls were rotated between herds over years. Cows were weighed monthly after an overnight fast. Condition scoring was done (scale of 1-5; Van Niekerk \& Louw, 1990) whenever a new phase of the production cycle was initiated. The trial ran from 1985 to 1990.

Supplement compositions are presented in Table 1. Cows received the summer supplements from approximately December until May. Winter maintenance supplements (approximately June until November) were available on an $a d$ lib. basis during the years 1986 to 1989. Treatments consisted of three levels of summer supplemental P, namely: control (CS: $8 \mathrm{~g} \mathrm{P} /$ cow/day), half (HS: $4 \mathrm{~g} \mathrm{P} /$ cow/day) and zero (ZS: $0 \mathrm{~g} \mathrm{P} /$ cow/day) levels. Winter treatments during 1990 were as follows: control (CW: $10 \mathrm{~g} \mathrm{P/cow/day);} \mathrm{half} \mathrm{(HW:} 5 \mathrm{~g} \mathrm{P} /$ cow/day) and zero (ZW: $0 \mathrm{~g}$ P/cow/day).

During summer each herd was assigned to a set of camps which was utilised by means of controlled selective grazing (Drewes, 1991). Sets of camps were rotated between herds over years. Oesophageal fistula samples of ingested veld were collected regularly (at camp changes prior to grazing) during summer. Samples were analysed for crude protein (CP) content (micro-Kjeldahl method) and in vitro dry matter digestibility (IVDMD) (Tilley \& Terry, 1963 as modified by Engels \& Van der Merwe, 1967). Phosphorus content of the fistula samples was determined colorimetrically (Fiske \& Subbarow, 1925) using an automatic flow system (Basson, 1974).

Table 1 Percentage composition of summer (mineral maintenance) and winter (protein/energy/mineral maintenance) supplements offered to cows grazing natural pasture in the western Highveld region of South Africa

\begin{tabular}{|c|c|c|c|c|c|}
\hline \multirow[b]{2}{*}{ Season } & \multirow[b]{2}{*}{ Year } & \multirow[b]{2}{*}{ Ingredient } & \multicolumn{3}{|c|}{ Treatment } \\
\hline & & & $\mathrm{C}^{1}$ & $\mathrm{H}^{2}$ & $\mathrm{Z}^{3}$ \\
\hline \multirow{4}{*}{$\begin{array}{l}\text { Summer } \\
\text { (December } \\
\text { to May) }\end{array}$} & $1985-1986$ & Dicalcium phosphate & 50 & 33.3 & 0 \\
\hline & & Sodium chloride & 50 & 66.6 & 100 \\
\hline & 1987-1989 & Dicalcium phosphate & 33.3 & 20 & 0 \\
\hline & & Sodium chloride & 66.6 & 80 & 100 \\
\hline \multirow{8}{*}{$\begin{array}{l}\text { Winter } \\
\text { (June to } \\
\text { October) }\end{array}$} & & Dicalcium phosphate & 22.2 & 22.2 & 22.2 \\
\hline & $1986-1989^{4}$ & Urea & 22.2 & 22.2 & 22.2 \\
\hline & & Maize meal & 22.2 & 22.2 & 22.2 \\
\hline & & Sodium chloride & 33.4 & 33.4 & 33.4 \\
\hline & & Dicalcium phosphate & 22.2 & 10.7 & 0 \\
\hline & 1990 & Urea & 22.2 & 25.4 & 28.5 \\
\hline & & Maize meal & 22.2 & 25.4 & 28.5 \\
\hline & & Sodium chloride & 33.4 & 38.5 & 43.0 \\
\hline
\end{tabular}

${ }^{1} \mathrm{C}=$ Control treatment: summer $8 \mathrm{~g}$ P/cow/day and winter $10 \mathrm{~g}$ P/cow/day; ${ }^{2} \mathrm{H}=$ Half treatment: summer $4 \mathrm{~g}$ P/cow/day and winter $5 \mathrm{~g} \mathrm{P} /$ cow/day; ${ }^{3} \mathrm{Z}=$ Zero treatment: summer and winter $0 \mathrm{~g}$ P/cow/day; ${ }^{4}$ All treatments received the same winter supplements

Rib samples were obtained by the method of Little (1972) as modified by Read (1984) from six randomly-selected cows from each treatment at the commencement (early lactation) and termination (weaning) of each summer grazing season. A $14 \mathrm{~mm}$ diameter core drill was used to obtain an $11 \mathrm{~mm}$ diameter bone sample. A full bone sample extending to the 
interior periosteum was taken without penetrating that membrane (Read, 1984). Bone samples were analysed for P content (Fiske \& Subbarow, 1925).

The general linear models procedure (GLMP) of Statistical Analysis Systems (SAS, 1985) was used for the analysis of data. Summer data were analysed as a $3 \times 5$ factorial with three levels of P supplementation and five years where main effects (supplements) are reported in the cases with no significant interaction $(p>0.05)$ between supplements and years. Although repeated measurements were done on the same animals over the trial period, the observations were treated as independent, mainly because of the $20 \%$ herd replacement every year, and also because of the reduction in carry-over effects during the intervening winter. Condition scores were analysed by means of two-way contingency tables with $\mathrm{P}$ supplementation and score as factors. A one-way analysis of variance was done on the winter data (three levels of $\mathrm{P}$ supplementation for one season) according to winter allocation. A $3 \times 3$ factorial analysis was done on the combination of summer and winter treatments, where only main effects are recorded, as there were no significant $(p>0.05)$ interactions. As year had a significant effect in all analyses, analysis of covariance was done on both summer and winter data. For summer data, year was treated as a factor with level of $\mathrm{P}$ supplementation as covariate. For the winter data, the summer treatment was defined as the factor with winter $\mathrm{P}$ level as covariate.

\section{Results and discussion}

Rainfall varied from below average for the first year to above average for subsequent years (Figure 1). The rainfall pattern was erratic with no month identifiable as the month of maximum rainfall. Nutritional value of veld is said to decrease after the month of maximum rainfall (Louw, 1979; Cronjé, 1990). This was manifested in this trial insofar as nutritional value tended to decrease as the season progressed, irrespective of higher rainfall in later months. Similar trends were reported by Cilliers (1984) and De Brouwer et al. (1993). In vitro dry matter digestibility of ingesta collected from oesphageal fistulae varied from 50 to $58 \%$, and CP content varied from 6 to $9 \%$ of DM. Phosphorus content varied considerably between years, but was generally found to be between 0.15 and $0.25 \%$ of DM. All the above-mentioned values were obtained from summer veld. According to the NRC (1984) guidelines, a pasture P content of $0.27 \%$ of DM is required for large-frame lactating cows. The concentrations recorded in this study are therefore indicative of a $\mathrm{P}$ deficiency, as contamination of the sample with salivary $\mathrm{P}$ would result in an over-estimation of actual $\mathrm{P}$ content of pasture.

Supplement intakes are presented in Table 2. The summer supplement was given on an ad lib. basis during the 1985/86 and 1986/87 seasons. The ZS group consumed large quantities of salt, especially during the second season when intakes were close to $250 \mathrm{~g} / \mathrm{cow} / \mathrm{day}$. This could be indicative of pica. Despite the high intake of salt, none of the toxicity symptoms described by De Waal et al. (1993), Spangenberg et al. (1993) or Spangenberg (1997) were observed. The composition of the supplement was subsequently adjusted in an attempt to equalise salt intakes between treatments (see Table 1), and intakes decreased to $92 \mathrm{~g} / \mathrm{cow} /$ day for the remaining summer seasons (1987/88 to 1989/90). This is equivalent to $0.844 \%$ of total DM intake, which is below the maximum tolerance level of $10 \%$ of total DM (NRC, 1984).

During the last three seasons target supplement intakes were adjusted to 150 (CS), 125 (HS) and 100 (ZS) $\mathrm{g} / \mathrm{cow} / \mathrm{day}$ in order to obtain the required $\mathrm{P}$ intake and to limit salt intake. Over the same period cows offered a supplement containing equal quantities of dicalcium phosphate $a d$ lib. consumed $168.5 \mathrm{~g}$ supplement/cow/day - equivalent to an intake of $13.48 \mathrm{~g} \mathrm{P}$ and $84 \mathrm{~g} \mathrm{NaCl} / \mathrm{cow} /$ day (De Brouwer et al., 1993). Protein is an essential ingredient of a winter maintenance supplement, as protein is the first-limiting nutrient during winter in this area (Du Toit et al., 1940). It has been reported that unsupplemented cows lose mass during winter on the eastern Highveld and that the mass loss is exacerbated when only P is supplemented (Van Niekerk \& Jacobs, 1985; Jacobs 1991). During the winters of 1986 to 1989, all cows had ad lib. access to a P-containing protein supplement (Table 1). Average winter P intake was $10 \mathrm{~g} /$ cow/day. The same supplement was given during winter in 1990, but the dicalcium phosphate content was altered (Table 1) to realise different levels of P intake (Table 2). The 1990 winter phase lasted for 175 days, after which the trial was terminated due to the poor condition of some of the animals which had not received supplemental P. This occurred despite a good rainfall season during 1989/90 (Fig. 1) which ensured that ample quantities of roughage were available. P intakes that were close to the expected levels. Crude protein intake was lower for the $\mathrm{CW}$ treatment (161 vs $210 \mathrm{~g} / \mathrm{cow} / \mathrm{day}$ for the other treatments), but was still sufficient in terms of requirements (NRC, 1984), the balance being contributed by intake from natural pasture. 


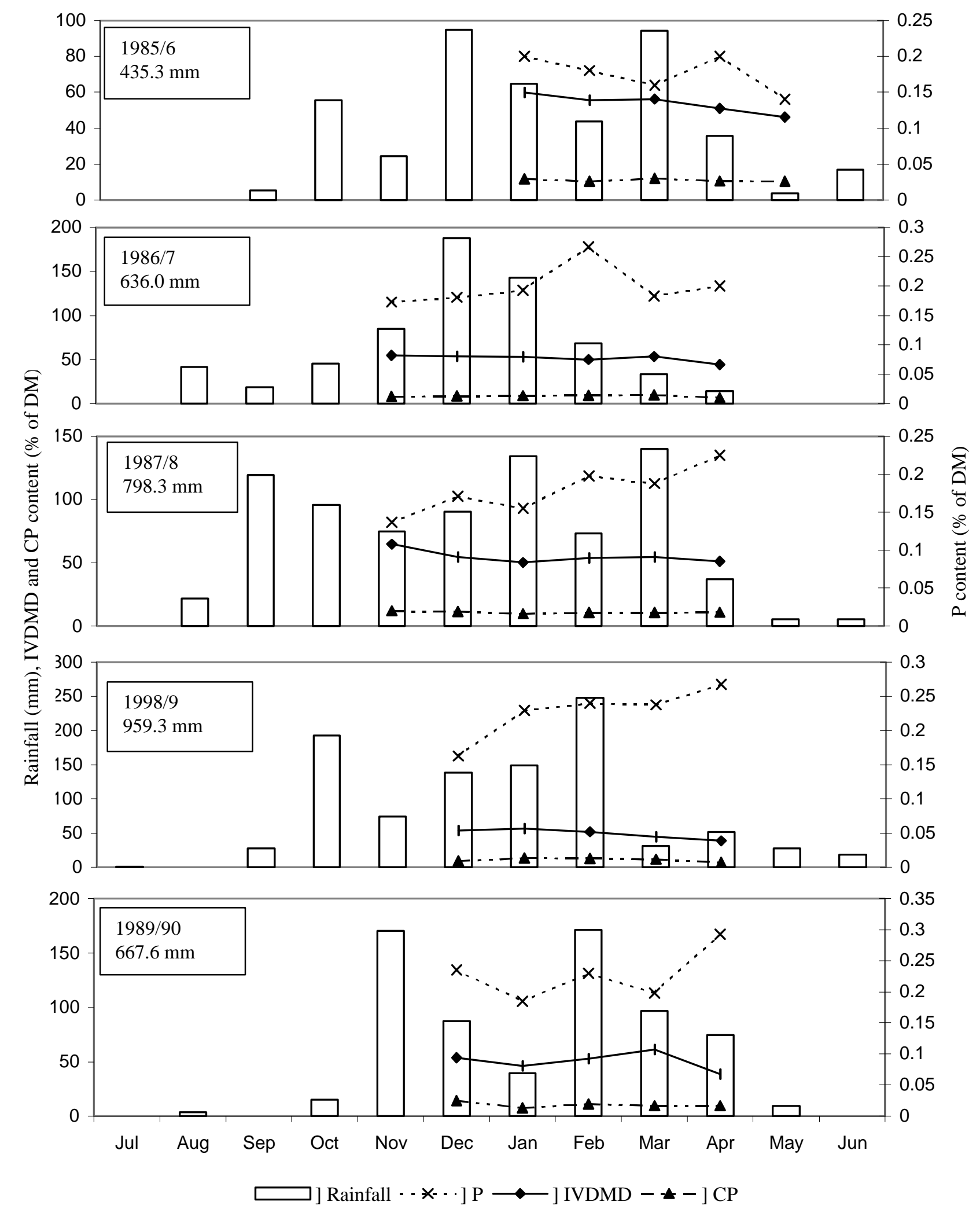

Figure 1 Rainfall $(\mathrm{mm})$ and nutritional value (from esophageal fistula samples) of natural pasture grazed by cows receiving different levels of phosphorous supplementation 
Table 2 Summer (mineral maintenance) and winter (protein/energy/mineral maintenance) supplement and phosphorus intakes (g/cow/day) of Simmentaler cows grazing Cymbopogon-Themeda veld (1985 - 1990)

\begin{tabular}{|c|c|c|c|c|c|c|}
\hline \multirow[t]{2}{*}{ Season } & \multirow[t]{2}{*}{ Year } & \multirow[t]{2}{*}{ Component } & \multirow[t]{2}{*}{ Period (d) } & \multicolumn{3}{|c|}{ Treatment } \\
\hline & & & & ${ }^{1} \mathrm{C}$ & ${ }^{2} \mathrm{H}$ & ${ }^{3} \mathrm{Z}$ \\
\hline \multirow[t]{10}{*}{ Summer } & $1985 / 86$ & Supplement & 128 & 105 & 96 & 183 \\
\hline & & Phosphorus & & 8.4 & 5.1 & 0 \\
\hline & $1986 / 87$ & Supplement & 140 & 145 & 172 & 234 \\
\hline & & Phosphorus & & 11.6 & 9.2 & 0 \\
\hline & $1987 / 88$ & Supplement & 122 & 138 & 122 & 98 \\
\hline & & Phosphorus & & 7.3 & 3.9 & 0 \\
\hline & $1988 / 89$ & Supplement & 127 & 146 & 97 & 100 \\
\hline & & Phosphorus & & 7.7 & 3.1 & 0 \\
\hline & $1989 / 90$ & Supplement & 161 & 120 & 120 & 86 \\
\hline & & Phosphorus & & 6.4 & 3.8 & 0 \\
\hline \multirow[t]{6}{*}{ Winter } & $1986-1986^{4}$ & Supplement & & 285 & 285 & 285 \\
\hline & & Phosphorus & & 10.1 & 10.1 & 10.1 \\
\hline & & Crude protein & & 181.6 & 181.6 & 181.6 \\
\hline & 1990 & Supplement & 175 & 257 & 295 & 261 \\
\hline & & Phosphorus & & 9.1 & 5.0 & 0 \\
\hline & & Crude protein & & 161 & 211 & 209 \\
\hline
\end{tabular}

${ }^{1} \mathrm{C}=$ Control treatment: summer $8 \mathrm{~g}$ P/cow/day and winter $10 \mathrm{~g} \mathrm{P} /$ cow/day ${ }^{2} \mathrm{H}=$ Half treatment: summer $4 \mathrm{~g}$ P/cow/day and winter $5 \mathrm{~g} \mathrm{P} /$ cow/day; ${ }^{3} \mathrm{Z}=$ Zero treatment: summer and winter $0 \mathrm{~g} \mathrm{P} /$ cow/day ${ }^{4}$ All treatments received the same winter supplements - average of four winters

A conception rate of $88 \%$ (including first-calf cows) was recorded. There were no differences in calving and weaning percentages between treatment groups. Calving and weaning rates were not used as a measure of reproductive efficiency, as cows with poor reproduction rates were culled from the herd. The variables used to assess performance are presented in Table 3. The figures presented are the means for five seasons. Replacement animals were allocated to treatments according to mass. Cows receiving the control treatment had the highest masses at the end of the summer seasons, and those receiving no supplemental P, the lowest $(p<0.01)$. Similar results were obtained at Armoedsvlakte (Read, 1984; De Waal \& Koekemoer, 1993; De Waal et al., 1993; De Waal et al., 1996; De Waal \& Koekemoer, 1997). Spangenberg et al. (1993) and Spangenberg (1997) reported mass differences of $59 \mathrm{~kg}$ between P-supplemented and unsupplemented cows, but ascribed this mass difference to salt toxicity in the latter group despite noticeable differences in bone $\mathrm{P}$ content $\left(141 \mathrm{vs} 128 \mathrm{mg} \mathrm{P} / \mathrm{cm}^{3}\right.$ ). It should be noted that in the present trial the cows also consumed relatively high levels of salt during the first two years (Table 2), before the supplementation regime was changed to prevent excessive intake. Mass gain during the season did not differ $(p>0.05)$ between the CS and HS treatments, which indicates that both levels of $\mathrm{P}$ supplementation enhanced weight-gain during lactation. The absence of clear differences between the CS and HS treatments may be partially ascribed to the fact that the actual consumption of supplemental P for the HS treatment was $61 \%$ of that for the CS treatment, and not $50 \%$ as planned. Supplemental P intake by the HS treatment was substantially more than half that of the CS treatment in four out of the five seasons. Analysis of covariance on mass gain, assuming linear regression on $\mathrm{P}$ level, detected no significant differences in regression coefficients over years. The common regression coefficient was $2.58 \mathrm{~kg} / \mathrm{g}$ P/day, which differs significantly $(p<0.01$ ) from zero (Table 3a). 
Table 3 Production responses of beef cattle to different levels of phosphorus supplementation to CymbopogonThemeda veld during summer in the western Highveld region (1985 - 1990)

Treatment

\begin{tabular}{ccc}
\multicolumn{3}{c}{ Treatment } \\
\hline $\mathrm{CS}$ & $\mathrm{HS}$ & $\mathrm{ZS}$ \\
$(8.3 \mathrm{~g} \mathrm{P} /$ cow $/$ day $)$ & $(5 \mathrm{~g} \mathrm{P} /$ cow $/$ day $)$ & $(0 \mathrm{~g} \mathrm{P} /$ cow $/$ day $)$
\end{tabular}

\section{Cows}

Autumn mass (kg)

Mass gain (kg)

Spring condition score (scale:1-5)

Autumn condition score (scale: $1-5)$

Change in condition score

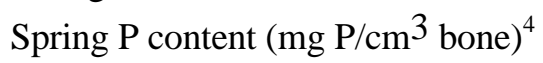

Autumn P content ( $\mathrm{mg} \mathrm{P}^{\mathrm{cm}} \mathrm{cm}^{3}$ bone) $548^{\mathrm{a}}$

$61^{\mathrm{a}}$

$2.75^{\mathrm{a}}$

$2.98^{\mathrm{a}}$

$0.23^{\mathrm{a}}$

$156.4^{\mathrm{a}}$

$141.9^{\mathrm{a}}$ $528^{\mathrm{b}}$

$59^{\mathrm{a}}$

$2.68^{\mathrm{a}}$

$2.97^{\mathrm{a}}$

$0.29^{\mathrm{a}}$

$137.7^{b}$

$130.8^{\mathrm{a}}$ $509^{\mathrm{c}}$

$40^{\mathrm{b}}$

$64^{\mathrm{a}}$

$2.69^{\mathrm{b}}$

$0.05^{\mathrm{b}}$

$139.4^{b}$

$112.6^{\mathrm{b}}$

\section{Calves}

Birth mass (kg)

$40^{\mathrm{a}}$

$38^{\mathrm{a}}$

$38^{\mathrm{a}}$

Weaning mass $(\mathrm{kg})$

$251^{\mathrm{a}}$

$250^{\mathrm{a}}$

$246^{\mathrm{a}}$

Weaning mass (kg at $205 \mathrm{~d}$ )

$244^{\mathrm{a}}$

$242^{\mathrm{a}}$

$240^{\mathrm{a}}$

Daily gain per day of age (g)

$998^{\mathrm{a}}$

$997^{\mathrm{a}}$

$985^{\mathrm{a}}$

abc Means with different superscripts within the same row differ $(p<0.01){ }^{4}$ Means with different superscripts in this row differ $(p$ $<0.05)$

Table 3a Analysis of covariance for production responses in beef cattle to different levels of phosphorus supplementation to Cymbopogon-Themeda veld during summer in the western Highveld region (response regressed on phosphorus supplementation level)

\begin{tabular}{|c|c|c|c|}
\hline & Regression coefficient (b) & Standard error $(\mathrm{Sb})$ & Significance \\
\hline Mass gain $(\mathrm{kg})$ & 2.58 & 0.948 & $<0.01$ \\
\hline Spring $\mathrm{P}$ content $\left(\mathrm{mg} \mathrm{P} / \mathrm{cm}^{3}\right)$ & 2.12 & 1.054 & $<0.05$ \\
\hline Autumn $\mathrm{P}$ content $\left(\mathrm{mg} \mathrm{P} / \mathrm{cm}^{3}\right)$ & 3.67 & 0.969 & $<0.01$ \\
\hline
\end{tabular}

Condition score at the start of the summer season was not affected by treatment $(p>0.05)$. All cows gained condition but the ZS cows had a very small improvement resulting in a lower $(p<0.01)$ autumn condition score. Treatment effects did not differ for variables measured on the calves $(p>0.05)$. Although there was no statistical difference between treatments, there was a trend with the same tendency every year for lower mass gain from birth to weaning with decreasing levels of $\mathrm{P}$ supplementation. Actual weaning weight was 4 and $5 \mathrm{~kg}$ heavier for the $\mathrm{HS}$ and CS treatments respectively than for the ZS treatment. The fact that the decrease was not statistically significant could possibly be ascribed to a maternal buffering effect, as the dam may have mobilised skeletal P reserves in order to maintain milk production.

Read (1984) examined various methods of estimating the $\mathrm{P}$ status of an animal, and concluded that the $\mathrm{P}$ content of bone tissue was the most accurate. Read (1984) found that skeletal P content was directly dependent on P intake and the production status of the animal. The status of animals is comparable when bone samples are obtained from the same numerical rib (Little \& Minson, 1977). Acceptable levels of bone mineralization are given as $140-150 \mathrm{mg} \mathrm{P} / \mathrm{cm}^{3}$ fresh bone, and deficiencies occur below $120 \mathrm{mg} \mathrm{P} / \mathrm{cm}^{3}$ fresh bone. Cattle with a bone $\mathrm{P}$ content of $120-140 \mathrm{mg} / \mathrm{cm}^{3}$ may be marginally deficient, depending on production status (Little \& Ratcliff, 1979; Little \& Shaw, 1979). The HS and ZS treatments had considerably lower bone P contents than the CS treatment at the start of the summer $(p<0.05)$. This was due to a cumulative effect. Levels at the start of the season were above the suggested deficiency cut-off level of $120 \mathrm{mg} \mathrm{P} / \mathrm{cm}^{3}$ bone. 
It must be remembered, however, that concentrations of $140-150 \mathrm{mg} \mathrm{P} / \mathrm{cm}^{3}$ bone are considered sufficient. Autumn bone $\mathrm{P}$ content was lower $(p<0.01)$ in the ZS group than in either of the P-supplemented groups. The CS group had a year-round bone $\mathrm{P}$ content within the sufficiency limits defined above, while neither of the other treatments were within these limits. Re-mineralisation occurred during winter, preventing the progressive depletion of $\mathrm{P}$ reserves recorded in the case of experiments conducted at Armoedsvlakte (Read, 1984). The greatest change in labile skeletal P reserves occurred in the ZS group and the least in the HS group. Despite annual winter replenishment of P reserves, unsupplemented cows were not able to avoid a deficiency developing when relying on summer veld to supply the dietary P requirements during lactation.

Analysis of covariance on autumn P content yielded a regression coefficient of $3.67 \mathrm{mg} \mathrm{P} / \mathrm{cm}^{3}$ bone per $\mathrm{g}$ $\mathrm{P} /$ cow/day which differed significantly $(p<0.01)$ from zero and did not differ over years (Table 3a). During 1990, eight cows from each summer treatment were allocated to one of three winter treatments. The results of the winter treatments are presented in Table 4.

Table 4 Responses of cows grazing Cymbopogon-Themeda veld in the western Highveld region (1990) to different levels of supplemental phosphorus during winter

\begin{tabular}{lccc}
\hline & \multicolumn{3}{c}{ Treatments } \\
\cline { 2 - 4 } Variable & $\begin{array}{c}\mathrm{CW} \\
\text { (9.1 g P/cow/day) }\end{array}$ & $\begin{array}{c}\text { HW } \\
(5 \mathrm{~g} \text { P/cow day })\end{array}$ & $\begin{array}{c}\mathrm{ZW} \\
(0 \mathrm{~g} \text { P/cow/day })\end{array}$ \\
\hline Autumn mass $(\mathrm{kg})$ & $540^{\mathrm{a}}$ & $545^{\mathrm{a}}$ & $532^{\mathrm{a}}$ \\
Pre-calf mass $(\mathrm{kg})$ & $559^{\mathrm{a}}$ & $570^{\mathrm{a}}$ & $538^{\mathrm{a}}$ \\
Spring mass $(\mathrm{kg})$ & $478^{\mathrm{a}}$ & $490^{\mathrm{b}}$ & $451^{\mathrm{c}}$ \\
Calf birth mass $(\mathrm{kg})$ & $37.9^{\mathrm{a}}$ & $39.5^{\mathrm{a}}$ & $40.4^{\mathrm{a}}$ \\
Autumn condition score (scale:1-5) & $2.90^{\mathrm{a}}$ & $3.00^{\mathrm{a}}$ & $2.83^{\mathrm{a}}$ \\
Pre-calf condition score (scale:1-5) & $2.77^{\mathrm{a}}$ & $2.77^{\mathrm{a}}$ & $2.54^{\mathrm{a}}$ \\
Spring condition score (scale:1-5) & $2.17^{\mathrm{a}}$ & $2.10^{\mathrm{a}}$ & $1.54^{\mathrm{b}}$ \\
Autumn P content (mg P/cm 3 bone) & $150.6^{\mathrm{a}}$ & $133.8^{\mathrm{a}}$ & $135.4^{\mathrm{a}}$ \\
Spring P content (mg P/cm 3 bone) & $147.7^{\mathrm{a}}$ & $130.6^{\mathrm{a}}$ & $74.5^{\mathrm{b}}$ \\
\hline
\end{tabular}

abc Means within the same row with different superscripts differ $(p<0.01)$

Table 4a Analysis of covariance: Cow response regressed on winter phosphorus supplementation with summer treatment as cofactor

\begin{tabular}{|c|c|c|c|}
\hline & Regression coefficient (b) & Standard error $(\mathrm{Sb})$ & Significance \\
\hline Spring mass (kg) & 2.73 & 1.687 & NS \\
\hline Spring $\mathrm{P}$ content $\left(\mathrm{mg} \mathrm{P} / \mathrm{cm}^{3}\right)$ & 7.318 & 1.880 & $<0.01$ \\
\hline
\end{tabular}

Initial (autumn) mass did not differ between treatments $(p>0.05)$ because of the reallocation of cows to the winter treatments. Pre-calf mass did not differ either $(p>0.05)$, but mass gain for the $\mathrm{CW}$ and HW treatments was 19 and $25 \mathrm{~kg}$ respectively, compared to $6 \mathrm{~kg}$ for the $\mathrm{ZW}$ treatment. The effect of supplemental protein on mass gain appeared to be reduced in the absence of $\mathrm{P}$ supplementation: mass gain was higher for the $\mathrm{CW}$ treatment than for the $\mathrm{ZW}$ treatment despite the fact that the crude protein intake of the $\mathrm{CW}$ treatment was $48 \mathrm{~g} / \mathrm{cow} /$ day lower than that of the $\mathrm{ZW}$ treatment (Table 2). Cow mass at the end of the trial period (after calving in spring) only differed insofar as the mass of the ZW treatment was less less than that of the HW treatment $(p<0.05)$; the mass of the HW treatment was also greater than that of the CW treatment. Spring masses for all treatments were relatively low compared to the general norm for large-frame type cows. Covariance analysis on spring mass with summer treatment as cofactor and winter supplementation as covariate revealed an effect of winter treatment on bone $\mathrm{P}$ content $(p<0.01)$, but no significant regression on winter treatment (spring mass), indicating that the differences in spring mass were mainly due to the summer treatments (Table $3 a$ ). 
All cows started the winter with a condition-score of 3, which is considered ideal. Despite the fact that all cows gained mass before calving, condition score decreased for all treatments during this time, indicating that the weight gain was associated with the growth of the foetus and associated tissues rather than maternal body tissues. A reduction in condition score of 0.5 is expected at calving. Final condition score was lower $(p<0.01)$ in the ZW group than in either of the other groups, whereas condition scores did not differ $(p>0.05)$ before calving. This can be ascribed to the fact that the $\mathrm{ZW}$ cows lost one point in condition score at calving compared to a loss of 0.6 and 0.67 condition points for the $\mathrm{CW}$ and HW treatments, respectively. The condition score of 1.54 recorded for the ZW treatment at the start of summer is extremely low for lactating beef cows nearing the mating season.

Bone $\mathrm{P}$ content in spring was extremely low for the $\mathrm{ZW}$ treatment, which did not receive $\mathrm{P}$ supplementation during the winter (Table 2). The bone-P status of this treatment decreased from sufficient $\left(135.4 \mathrm{mg} \mathrm{P} / \mathrm{cm}^{3}\right)$ to that of acute deficiency $\left(74.5 \mathrm{mg} \mathrm{P} / \mathrm{cm}^{3}\right)$ within 175 days (Table 4). In this group of 24 cows, three died of emaciation and other complications brought about by aphosphorosis, while another had to be destroyed as a result of a fractured pelvis which occurred during mating in the subsequent mating season. The remainder of the group displayed classic symptoms of aphosphororis (Theiler \& Green, 1932) including stiff gait, emaciation, incoordination, coarse hair and accelerated hoof growth. At the termination of the trial, these and the HW cows were given access to the P-containing supplement given to the $\mathrm{CW}$ treatment. Recovery was dramatic. No symptoms or fatalities were observed for the other two groups. These results suggest that reproducing cows need supplementary P during winter (i.e. during the period when they are not lactating), which contradicts the findings of Jacobs (1991). Analysis of covariance also indicated the presence of an effect of summer treatment on final bone $\mathrm{P}$ content $(p<0.01)$, as well as a highly significant regression between bone $\mathrm{P}$ content and winter $\mathrm{P}$ treatment $\left(7.32 \mathrm{mg} \mathrm{P} / \mathrm{cm}^{3}\right.$ bone per $\mathrm{g} \mathrm{P} /$ cow/day; Table $\left.4 \mathrm{a}\right)$. Neither treatment that received supplemental $\mathrm{P}$ during the winter ( $\mathrm{CW}$ or $\mathrm{HW}$ ) displayed bone $\mathrm{P}$ contents that could be classified as indicative of $\mathrm{P}$ deficiency. The bone $\mathrm{P}$ content of the CW group fell within desired levels (above $140 \mathrm{mg} \mathrm{P} / \mathrm{cm}^{3}$ ). The influence of different combinations of winter and summer $\mathrm{P}$ supplement levels on cow mass, condition score and bone $\mathrm{P}$ content is shown in Table 5. Treatment combinations represent the means of eight cows for each combination.

Table 5 Effect of different combinations of supplementary treatments on cow mass, condition score and bone phosphorus content (1990)

\begin{tabular}{lcccc}
\hline \multicolumn{2}{l}{ Treatment combination } & \multicolumn{3}{c}{ Variable } \\
\cline { 3 - 5 } Winter $^{1}$ & Summer $^{2}$ & $\begin{array}{c}\text { Final mass } \\
(\mathrm{kg})\end{array}$ & $\begin{array}{c}\text { Final condition score } \\
(1-5)\end{array}$ & $\begin{array}{c}\text { Final P content }^{3} \\
\left(\mathrm{mg} \mathrm{P} / \mathrm{cm}^{3}\right)\end{array}$ \\
\hline $\mathrm{CW}$ & $\mathrm{CS}$ & $485^{\mathrm{a}}$ & 2.25 & $175.9^{\mathrm{a}}$ \\
$\mathrm{CW}$ & $\mathrm{HS}$ & $483^{\mathrm{ab}}$ & 2.38 & $140.6^{\mathrm{a}}$ \\
$\mathrm{CW}$ & $\mathrm{ZS}$ & $467^{\mathrm{ab}}$ & 1.88 & $126.5^{\mathrm{a}}$ \\
$\mathrm{HW}$ & $\mathrm{CS}$ & $502^{\mathrm{a}}$ & 2.44 & $164.3^{\mathrm{a}}$ \\
$\mathrm{HW}$ & $\mathrm{HS}$ & $482^{\mathrm{ab}}$ & 1.94 & $141.1^{\mathrm{a}}$ \\
$\mathrm{HW}$ & $\mathrm{ZS}$ & $486^{\mathrm{a}}$ & 1.94 & $86.3^{\mathrm{b}}$ \\
$\mathrm{ZW}$ & $\mathrm{CS}$ & $486^{\mathrm{a}}$ & 1.88 & $85.9^{\mathrm{b}}$ \\
ZW & $\mathrm{HS}$ & $471^{\mathrm{ab}}$ & 1.75 & $73.6^{\mathrm{b}}$ \\
ZW & ZS & $396^{\mathrm{b}}$ & 1.00 & $63.9^{\mathrm{b}}$ \\
\hline
\end{tabular}

${ }^{1}$ CW: 9.1 g P/cow/day; HW: 5 g P/cow/day; ZW: 0 g P/cow/day; ${ }^{2}$ CS: 8.3 g P/cow/day; HS: 5 g P/cow/day; ZS: 0 g P/cow/day;

${ }^{3}$ Mean of two samples. ${ }^{\text {ab }}$ Means within columns with different superscripts differ $(p<0.01)$ 
Table 5a Analysis of variance summary statistics for final bone $\mathrm{P}$ content

\begin{tabular}{lccccc}
\hline & df & SS X 10 & MS X 10 & F & Significance \\
Source & 2 & 17.59 & 8.79 & 20.73 & $\mathrm{P}<0.01$ \\
Winter treatment & 2 & 7.45 & 3.73 & 8.78 & $\mathrm{P}<0.01$ \\
Summer treatment & 4 & 2.05 & 0.51 & 1.21 & NS \\
Interaction & 9 & 3.82 & 0.42 & & \\
Error & 17 & 30.91 & & & \\
\hline Total & & &
\end{tabular}

Cows that did not receive P supplementation for one year had lower final body masses $(p<0.01)$ and condition scores than other treatment combinations. Condition scores were not analysed statistically due to the small sample size relative to the number of categories. Simmentaler cows with an average mass of less than $480 \mathrm{~kg}$ six weeks before the mating season and a condition score below 2 will probably not realise high conception rates. Only treatment combinations $\mathrm{CS} / \mathrm{CW}, \mathrm{CS} / \mathrm{HW}$ and $\mathrm{HS} / \mathrm{CW}$ were capable of maintaining a condition score above 2 and an acceptable mass. The effects of the low bone $\mathrm{P}$ content, condition score or mass on reproduction could not be determined, as all the cows received a dicalcium phosphate supplement at the termination of the trial. Bone $\mathrm{P}$ contents given in Table 5 are the means of only two cows per treatment combination, but show a significant decrease (Table 5a) in bone P content with decreasing levels of supplemental P.

\section{Conclusions}

Reproducing cows on the western Highveld should be supplemented with 8.3-9.1 g P/cow/day throughout the year. P-supplementation during winter should be accompanied by protein supplementation.

\section{Acknowledgments}

The authors thank J.W. Roux for support with the statistical analysis of the data, E van der Merwe for surgical procedures involving rib-sample collection and M Postma for assistance with pasture management. The authors are indebted to the late F Nel and also H.P. Nonyane, M.S. Seipei, S.R. Letshabo and F Semelane for their conscientious management of the animals.

\section{References}

Acocks, J.P.H., 1988. Veld types of South Africa, (3rd edn.). Mem. Bot. Surv. S. Afr. 56. Government printer, Pretoria. Basson, W.D., 1974. A semi-mechanised procedure for the simultaneous determination of nitrogen and phosphorus in animal feeds with a continuous flow system. Protea Laboratory News, Aug. 1974.

Cilliers, J.W., 1984. Vleisproduksie vanaf onbemeste- en bemeste Cymbopogon-Themeda somerveld. Ph.D. thesis, University of the Orange Free State, Bloemfontein.

Cronjé, P.B., 1990. Supplementary feeding of ruminants - a physiological approach. S. Afr. J. Anim. Sci. 20, 110.

De Brouwer, C.H.M., Visser, C.B., Schutte A.R. \& Postma, M., 1993. Biological and economical effects of different supplements given to beef cows on summer veld. S. Afr. J. Anim. Sci. 23, 31.

De Waal, H.O., 1979. Die voedingswaarde van veldweiding van die sentrale Oranje Vrystaat met spesiale verwysing na die rol van proteien- en fosforaanvulling. MSc thesis, University of Stellenbosch.

De Waal, H.O. \& Koekemoer, G.J., 1993. The effects of different levels of phosphorus supplementation to beef cows at Armoedsvlakte in the northern Cape. Proc. 32nd Congress of the South African Society of Animal Science. Wild Coast Sun, Republic of Transkei.

De Waal, H.O., Jonker, M.L., Agenbag, G.J., Smith, J.M. \& Van Zyl, C.B., 1993. The effects of phosphorus supplementation to beef cows at two sites (Vaalharts and Koopmansfontein) in the northern Cape. Proc. 32nd Congress of the South African Society of Animal Science. Wild Coast Sun, Republic of Transkei.

De Waal, H.O. \& Koekemoer. G.J., 1997. Blood, rib, bone and rumen fluid as indicators of phosphorus status of grazing beef cows supplemented with different levels of phosphorus at Armoedsvlakte. S. Afr. J. Anim. Sci. 27, 76.

De Waal, H.O., Randall, J.H. \& Koekemoer. G.J., 1996. The effects of phosphorus supplementation on body mass and reproduction of grazing beef cows supplemented with different levels of phosphorus at Armoedsvlakte. S. Afr. J. Anim. Sci. 26, 29. 
Drewes, R.H., 1991. The Potch system: An approach to the management of semi-arid grasslands in southern Africa. J. Grassl. Soc. South Afr. 8, 174.

Du Toit, P.J., Louw, J.G. \& Malan, A.I., 1940. A study of the mineral and feeding value of natural pastures in the Union of South Africa. Onderstepoort J. Vet. Sci. 14, 123.

Engels, E.A.N., 1981. Mineral status and profiles (blood, bone and milk) of the grazing ruminant with special reference to calcium, phosphorus and magnesium. S. Afr. J. Anim. Sci. 11, 171.

Engels, E.A.N. \& Van der Merwe, F.J., 1967. Application of an in vitro technique to South African forages with special reference to the effect of certain factors on results. S. Afr. J. Agric. Sci. 10, 983.

Ferreira, B., 1976. Die rol, voorkoms en aanvulling van kalsium en fosfor in dierevoeding. Glen Agric. 5 (2), 25.

Fiske, C.H. \& Subbarow, Y., 1925. The colorimetric determination of phosphorus. J. Biol. Chem. 66, 375.

Groenewald, I.B., 1986. Die invloed van stikstof-, energie- en fosforbevattende lekaanvullings op die reproduksie- en produksievermoë van koeie op natuurlike weiding. Ph.D.thesis, University of the Orange Free State, Bloemfontein.

Heard, C.A.H., 1971. The influence of pasture fertilization on animal health. Proc. Grassld Soc. S. Afr. 6, 134.

Hemingway, R.G., 1967. Phosphorus and the ruminant. Outlook on Agriculture 5, 172.

Jacobs, G.A., 1991. Phosphorus supplementation to pregnant cows during wintering on low quality roughage. Proc. 30th. Congress of the South African Society of Animal Science. Port Elizabeth, South Africa.

Little, D.A., 1970. Factors of importance in the phosphorus nutrition of beef cattle in Northern Australia. Aust. Vet. J. 46, 241.

Little, D.A., 1972. Bone biopsy in cattle and sheep for studies of phosphorus status. Aust. Vet. J. 46, 241.

Little, D.A. \& Minson, D.J., 1977. Variation in phosphorus content of bone samples obtained from the last three ribs of cattle. Res. Vet. Sci. 23, 393.

Little, D.A. \& Ratcliff, D., 1979. Phosphorus content of the bovine rib: influence of earlier biopsy on the same rib. Res. Vet. Sci. 27, 239.

Little, D.A. \& Shaw, N.H., 1979. Superphosphate and stocking rate effects on a native pasture oversown with Stylosanthes humilis in central coastal Queensland. Aust. J. Exp. Agric. Anim. Husb. 19, 645.

Matches, A.G., Martz, F.A. \& Thompson, G.B., 1974. Multiple assignment tester animals for pasture-animal systems. Agron. J. 66, 719.

NRC, 1984. Nutrient requirements of beef cattle (6th ed.). National Academy Press, Washington D.C.

Read, M.V.P., 1984. Animal performance from natural pastures and the effects of phosphorus supplementation. MSc (Agric) thesis, University of Stellenbosch.

SAS, 1985. Statistical analysis systems user's guide (5th ed.). SAS Institute Inc., Raleigh, North Carolina.

Spangenberg, H.P., 1997. Phosphorus supplementation to grazing beef cows at two sites in the Northern Cape. Ph.D. thesis, University of the Orange Free State, Bloemfontein.

Spangenberg, H.P., De Waal, H.O., Van Den Heever, M.J., Scholtz, H.P.J. \& Smith, J.M., 1993. The effect of phosphorus supplementation on the production and reproduction of cattle on veld at Saratoga in the northern Cape. Proc. 32nd Congress of the South African Society of Animal Science. Wild Coast Sun, Republic of Transkei.

Theiler, A. \& Green, H.H., 1932. Aphosphorosis in ruminants. Nutr. Abstr. Rev. 1, 359.

Theiler, A., Green, H.H. \& Du Toit, P.J., 1927. Minimum mineral requirements in cattle. J. Agric. Sci. 17, 291.

Tilley, J.M.A. \& Terry, R.A., 1963. A two-stage technique for the in vitro digestion of forage crops. J. Br. Grassld. Soc. $18,104$.

Van Niekerk, B.D.H. \& Jacobs, G.A., 1985. Protein, energy and phosphorus supplementation of cattle fed low quality forage. S. Afr. J. Anim. Sci. 15, 133.

Van Niekerk, A. \& Louw, B.P., 1990. Condition scoring of beef cattle. Dept. Agriculture, Natal Region. Directorate Agricultural Information, Private Bag X144, Pretoria, 0001. 